\title{
UJI EFEKTIVITAS SEDIAAN GEL SABUN WAJAH EKSTRAK DAUN KEMANGI (Ocimum basilicum L.) TERHADAP BAKTERI Staphylococcus aureus
}

\author{
Anggun Maksumah ${ }^{1}$ Rifqi Ferry Balfas ${ }^{* 2}$ Hanari Fajarini ${ }^{3}$ Iqbal Yulianto ${ }^{4}$ \\ 1,2*3,4 Program Studi Farmasi, Fakultas Ilmu Kesehatan, Universitas Muhadi Setiabudi Brebes, Indonesia \\ e-mail: ${ }^{1}$ anggunlaelatul23@gmail.com, ${ }^{* 2}$ rifqi.ferry.balfas@gmail.com, ${ }^{3}$ hanari.fajarini@gmail.com, \\ iqubalmughni2@gmail.com
}

\begin{abstract}
ABSTRAK
Daun kemangi (Ocimum basilicum L.) merupakan salah satu tanaman obat yang memiliki efektivitas menghambat bakteri Staphylococcus aureus. kandungan senyawa pada daun kemangi yaitu flavonoid dan fenol. Penelitian ini bertujuan untuk mengetahui efektivitas sediaan gel sabun wajah ekstrak daun kemangi terhadap bakteri Staphylococcus aureus. Data penelitian ini adalah data primer. Metode analisis data menggunkan analisis deskriptif dan metode efektivitas antibakteri menggunakan metode difusi agar. Sampel yang digunakan pada penelitian yaitu daun kemangi diekstraksi menggunakan larutan etanol $96 \%$ dengan cara maserasi. Ekstrak dibuat dalam tiga formula dengan FI : 1 gram, FII : 1,5 gram dan FIII : 2 gram. Evaluasi sediaan dengan uji organoleptik, uji homogenitas, uji pH, uji daya sebar dan uji efektivitas. Hasil formulasi menunjukkan daya hambat FI: $5 \mathrm{~mm}$, FII : $8 \mathrm{~mm}$ dan FIII : $9 \mathrm{~mm}$, ini dapat diartikan bahwa tiap formula memiliki daya hambat. Ketiga formula tersebut termasuk dalam katagori zona hambat sedang, tetapi yang memiliki zona hambat yang paling luas yaitu F3 : 9 mm. Semakin banyak ekstrak maka zona hambat semakin luas. Sehingga dapat disimpulkan bahwa sediaan gel sabun wajah ekstrak daun kemangi memiliki efektivitas terhadap bakteri Staphylococcus aureus.
\end{abstract}

Kata kunci : Ekstrak daun kemangi, gel sabun wajah, Staphylococcus aureus, uji efektivitas

\begin{abstract}
Basil leaves (Ocimum basilicum L.) is a medicinal plant that has the effectiveness of inhibiting Staphylococcus aureus bacteria. The content of compounds in basil leaves, namely flavonoids and phenols. This study aims to determine the effectiveness of basil leaf extract facial soap gel preparation against Staphylococcus aureus bacteria. The data of this research are primary data. The data analysis method used descriptive analysis and the antibacterial effectiveness method used the agar diffusion method. The sample used in this study was the basil leaves extracted using $96 \%$ ethanol solution by means of maceration. The extract is made in three formulas with FI: 1 gram, FII: 1.5 grams and FIII: 2 grams. Evaluation of preparations by organoleptic test, homogeneity test, $\mathrm{pH}$ test, spreadability test and effectiveness test. The formulation results show the inhibition of FI: $5 \mathrm{~mm}$, FII: $8 \mathrm{~mm}$ and FIII: $9 \mathrm{~mm}$, this means that each formula has an inhibitory power. The three formulas are included in the moderate inhibition zone category, but the one with the most extensive zone of inhibition is F3: $9 \mathrm{~mm}$. The more extract, the wider the inhibition zone. So it can be concluded that the basil leaf extract facial soap gel preparation has effectiveness against Staphylococcus aureus bacteria.
\end{abstract}

Keywords : Basil leaf extract, facial soap gel, staphylococcus aureus, effectiveness test 


\section{PENDAHULUAN}

Bagian manusia yang sering nampak dan mudah terkena bakteri adalah kulit, karena kulit merupakan organ tubuh terluar dari organ lainnya yang sering terkontak dengan lingkungan hidup manusia. Permukaan kulit banyak mengandung nutrisi untuk pertumbuhan organisme antara lain lemak, nitrogen dan mineral yang menyebabkan berbagai macam penyakit pada kulit.[1] Masalah kulit yang utama dan mengakibatkan perubahan di bagian wajah adalah jerawat yang menimbulkan perubahan pada kulit seperti bengkak kemerahan, bernanah yang menimbulkan rasa sakit.[2] Bakteri Staphylococcus aureus adalah salah satu penyebab jerawat dan beberapa faktor lain seperti keturunan, hormonal, polusi udara, dan makanan yang dapat ditemukan pada muka, rambut, tangan, dan saluran pernafasan atas.[3]

Dalam pengobatan biasanya jerawat belum dapat dihilangkan secara tuntas, namun untuk pengobatan jerawat dapat secara non farmakologi dan farmakologi. Pengobatan jerawat secara non farmakologi dengan cara rutin membersihkan muka, menggunakan penutup muka seperti masker dan menerapkan hidup bersih. Sedangkan secara farmakologi dengan menggunakan obat jerawat seperti klindamisin dan obat herbal. Salah satu contoh obat herbal untuk mengatasi jerawat adalah daun kemangi.[2] Daun kemangi tanaman yang umum bagi masyarakat karena banyak manfaat dan mempunyai kandungan satu atau lebih bahan aktif. Obat herbal lebih mudah diperoleh dan harganya relatif lebih murah dan meminimalkan efek samping yang banyak terjadi pada pengobatan jerawat.

Kandungan ekstrak daun kemangi yang berkhasiat antibakteri yaitu flavonoid dan fenol. Ekstrak daun kemangi (Ocimum basilicum L.) pada konsentrasi 100\% dan 80\% dapat menghambat Kadar Hambat Minimum (KHM) dan Kadar Bunuh Minimum (KBM) pada Staphylococcus aureus.[4] Peneliti lain membuktikan bahwa bakteri Staphylococcus aureus dapat dihambat dengan ekstrak daun kemangi dengan zona hambat $16 \mathrm{~mm}$ pada konsentrasi $200 \mathrm{mg} / \mathrm{mL}$.[5] Pada penelitian ini, ekstrak daun kemangi akan diformulasi menjadi gel sabun wajah. Diformulasi dalam bentuk gel sabun wajah karena masih kurangnya sediaan gel sabun wajah khususnya untuk mengatasi bakteri pada kulit. Dari segi penggunaanya sabun lebih mudah digunakan. Keuntungan sediaan gel yaitu tidak mengandung minyak dan memiliki formulasi hidrogel yang tidak membuat kulit menjadi kering dan aman untuk jerawat. Sabun dipilih sebagai tambahan agar memiliki aroma khas dan menciptakan variasi sediaan gel sabun. Tujuan Penelitian ini untuk mengetahui efektivitas sediaan gel sabun wajah ekstrak daun kemangi terhadap Bakteri Staphylococcus aureus. Oleh karena itu penulis bermaksud melakukan penelitian dengan judul "Uji Efektivitas Sediaan Gel Sabun Wajah Ekstrak Daun Kemangi (Ocimum basilicum L.) terhadap Bakteri Staphylococcus aureus".

\section{METODE PENELITIAN}

Penelitian ini dilakukan dengan metode ekperimental di laboratorium farmasi Universitas Muhadi Setiabudi.

\subsection{Alat dan Bahan}

Alat yang digunakan timbangan digital, blender, gelas beaker, gelas ukur, cawan petri, cawan porselen, mortir, oven, inkubator, kertas $\mathrm{pH}$, aluminium foil, batang pengaduk, kertas saring, kaca transparan, kaki tiga, bunsen, ose/sengkelit, erlenmeyer, pipet tetes, mistar berskala.

Bahan - bahan yang digunakan daun kemangi diambil di Desa Karanganyar Kec. Pagerbarang Kab. Tegal, etanol 96\%, natrium metabisulfit, sodium lauril sulfat, kokamidopropil betain, kokamid DEA, propilen glikol, dinatrium EDTA, metil paraben dan propil pareben, nutrient agar, mueller hinton agar, karbomer, parfum, aquadest, brain heart infusion, tween 80, larutan $\mathrm{NaOH}$. 


\subsection{Jalannya Penelitian}

a. Pengambilan Sampel

Jenis sampel daun kemangi (Ocimum Basilicum L.) hijau diambil dari Desa Karanganyar Kec. Pagerbarang Kab. Tegal. Sampel daun yang digunakan daun hijau segar dan tidak berjamur.

b. Pengolahan sampel

Daun kemangi dibersihkan dari kotoran. Kemudian dikeringkan dengan cara diangin-anginkan di tempat yang tidak terkena sinar matahari langsung. Setelah daun kemangi kering lalu diblender menjadi serbuk, sampel siap diekstraksi.

Proses pembuatan sediaan gel sabun wajah dimulai dari masukkan secara berurutan sodium lauril sulfat, kokamide DEA, sebagian kokamidropropil betain, dan sebagian propilen glikol yang sudah terlarut, metil paraben dan propil paraben sambil digerus secara perlahan dengan mortir sampai homogen. Kembangkan karbomer dengan aquadest, diamkan selama 1 hari dan setelah itu ditambahkan sebagaian aquadest yang sudah terlarut natrium metabisulfit dan dinatrium EDTA dan larutan $\mathrm{NaOH}$ gerus dengan mortir hingga homogen. Masukkan campuran 1 ke dalam campuran 2 sedikit demi sedikit sambil diaduk dengan mortir sampai homogen. Ditambahkan ekstrak daun kemangi yang telah dicampuri dengan sisa propilen glikol dan sisa kokamidropil betain, aduk hingga homogen. Tambahkan parfum dan sisa air suling yang tersisa, lalu dihomogenkan dengan mortir. Lakukan evaluasi terhadap sediaan gel sabun wajah.[6]

\subsection{Ekstrak Sampel}

Cara pembuatan ekstrak daun kemangi, Timbang serbuk simplisia ekstrak daun kemangi Sebanyak 160 gram, serbuk simplisia daun kemangi dimasukkan ke dalam wadah. Lalu maserasi serbuk simplisia daun kemangi direndam dengan larutan etanol 96\% sebanyak $800 \mathrm{ml}$, ditutup dengan aluminium foil dan dibiarkan selama 2 hari sambil sesakali diaduk. Setelah 2 hari, sampel yang direndam tersebut disaring menggunakan kertas saring menghasilkan filtrat 1 dan residu 1 . Residu yang ada kemudian ditambah dengan larutan etanol $96 \%$ sebanyak $480 \mathrm{ml}$, ditutup dengan aluminium foil dan dibiarkan selama 1 hari sambil sesekali diaduk. Setelah 1 hari, sampel tersebut disaring menggunakan kertas saring menghasilkan filtrat 2 dan residu 2. Filtrat 1 dan 2 dicampur menjadi satu, sehingga diperoleh ekstrak daun kemangi. Ekstrak daun kemangi lalu dimasukkan ke dalam cawan porselen untuk dipekatkan di atas penangas air. Ekstrak ditimbang dan disimpan dalam wadah tertutup sebelum digunakan untuk pengujian.[7]

\subsection{Rancangan formulasi gel sabun wajah}

Tabel 3.4.3 Formulasi gel sabun wajah

\begin{tabular}{lrrrr}
\hline \multicolumn{1}{c}{ Komponen } & Formula I & Formula II & Formula III \\
\hline Basil leaf Ext & 1 gram & 1,5 gram & 2 gram \\
Sodium Lauril Sulfat & 10 gram & 10 gram & 10 gram \\
Kokamide DEA & $3 \mathrm{ml}$ & 3 & $\mathrm{ml}$ & $3 \mathrm{ml}$ \\
Kokamidopropil Betain & $8 \mathrm{ml}$ & 8 & $\mathrm{ml}$ & $8 \mathrm{ml}$ \\
Propilen Glikol & $10 \mathrm{ml}$ & $10 \mathrm{ml}$ & $10 \mathrm{ml}$ \\
Metil Paraben & 0,1 gram & 0,1 gram & 0,1 gram \\
Propilen Paraben & 0,05 gram & 0,05 gram & 0,05 gram \\
Karbomer & 0,5 gram & 0,5 gram & 0,5 gram \\
Dinatrium EDTA & 0,1 gram & 0,1 gram & 0,1 gram
\end{tabular}




\begin{tabular}{lrrr} 
Natrium Metabisulfit & 0,1 gram & 0,1 gram & 0,1 gram \\
Larutan $\mathrm{NaOH}$ & $0,15 \mathrm{ml}$ & $0,15 \mathrm{ml}$ & $0,15 \mathrm{ml}$ \\
Parfum & $2 \mathrm{ml}$ & $2 \mathrm{ml}$ & $2 \mathrm{ml}$ \\
Aquades ad. & qs & qs & qs \\
M.f Saponem gel facialis & $\mathbf{3 5}$ gram & $\mathbf{3 5 , 5}$ gram & $\mathbf{3 6}$ gram \\
\hline
\end{tabular}

\subsection{Pembuatan gel sabun wajah}

Dimasukkan secara berurutan sodium lauril sulfat, kokamide DEA, sebagian kokamidropropil betain, dan sebagian pro pilen glikol yang sudah terlarut, metil paraben dan propil paraben sambil digerus secara perlahan dengan mortir sampai homogeny. Kembangkan karbomer dengan aquadest, diamkan selama 1 hari. Karbomer yang sudah didiamkan selama 1 hari ditambahkan sebagaian aquadest yang sudah terlarut natrium metabisulfit dan dinatrium EDTA dan larutan $\mathrm{NaOH}$ gerus dengan mortir hingga gel sabun menjadi kaku dan jernih. Dimasukkan campuran 1 ke dalam campuran 2 sedikit demi sedikit sambil diaduk dengan mortir sampai homogen. Ditambahkan ekstrak daun kemangi yang telah dicampuri dengan sisa propilen glikol dan sisa kokamidropil betain, aduk hingga homogen. Ditambahkan parfum dan sisa air suling yang tersisa, lalu dihomogenkan dengan mortir. Dilakukan evaluasi terhadap sediaan gel sabun wajah.[6]

\subsection{Uji Organoleptik}

Uji organoleptik dilakukan dengan mengamati tampilan fisik sediaan dengan cara melakukan pengamatan terhadap bentuk, warna, dan bau dari gel sabun wajah ekstrak daun kemangi.[11]

\subsection{Uji Homogenitas}

Pengujian homogenitas dilakukan dengan cara gel sabun wajah ekstrak daun kemangi ditimbang sebanyak 0,1 gram kemudian dioleskan pada sekeping kaca transparan kemudian diamati. Homogenitas ditunjukkan dengan tidak adanya butiran kasar.[7]

\subsection{Uji PH}

Pengukuran $\mathrm{pH}$ sediaan dilakukan dengan menggunakan kertas $\mathrm{pH}$. Sebanyak 1 gram gel sabun wajah kemudian dilarutkan dengan aquades sebanyak $10 \mathrm{ml}$ lalu diaduk sampai merata. pH meter dicelupkan ke dalam sediaan yang telah dilarutkan, diamkan beberapa saat dan hasilnya dilihat pada indikator $\mathrm{pH}$ meter stabil dan menunjukkan nilai $\mathrm{pH}$ konstan. $\mathrm{pH}$ sediaan yang memenuhi kriteria $\mathrm{pH}$ kulit yaitu berkisar 4,5 - 6,5.[7]

\subsection{Uji Daya sebar}

Sebanyak 0,5 gram gel sabun wajah ekstrak daun kemangi diletakkan diatas cawan petri berdiameter $15 \mathrm{~cm}$, kaca lainnya diletakkan diatas gel sabun wajah dan dibiarkan selama 1 menit. Diameter sebar gel sabun wajah diukur. Setelah diukur ditambahkan 50 gram beban tambahan dan didiamkan selama 1 menit lalu diukur diameter yang konstan. Daya sebar sediaan semi padat yang baik untuk penggunaan topikal berkisar pada diameter $5 \mathrm{~cm}-7 \mathrm{~cm}$.[7]

\subsection{Persiapan Bakteri Uji}

Bakteri yang telah digunakan ditanam terlebih dahulu pada Nutrient Agar (NA) yang telah disterilkan pada suhu $121^{\circ} \mathrm{C}$ selama 15 menit. Diinkubasi selama 24 jam pada temperatur $37^{\circ} \mathrm{C}$. Bakteri yang berumur 24 jam ambil dengan ose/sengkelit dimasukkan ke dalam erlenmeyer yang berisi $5 \mathrm{~mL}$ larutan Brain Heart Infusion (BHI) sehingga didapat kekeruhan $25 \% \mathrm{~T}$. Sediaan uji diencerkan menggunakan aquadest steril, tambahkan tween 80 steril $0,5 \%$ bila sediaan uji tidak bercampuran dengan air.[6] 


\subsection{Pembuatan Media}

Tuang sebanyak kurang lebih $15 \mathrm{~mL}$ Mueller Hinton Agar ke dalam cawan petri steril lalu diamkan, setelah membeku diatasnya tuang $1 \mathrm{~mL}$ suspensi bakteri ke atas media, goyanggoyang sampai suspensi terbagi rata di atas media ad homogen dan memadat.[6]

\subsection{Uji Efektivitas Gel Sabun Wajah}

Buat sumuran pada agar dan masukkan bahan uji menggunakan pipet tetes ke dalam sumuran agar yang telah dilapisi bakteri uji. Inkubasikan dalam inkubator pada suhu $37^{\circ} \mathrm{C}$ selama 24 jam. Setelah itu diukur diameter zona hambat (zona jernih) disekitar sumuran menggunakan mistar berskala dengan cara mengukur secara horizontal dan vertikal.[7]

\subsection{Analisis Data}

Gel sabun wajah yang dihasilkan dianalisis uji organoleptik, homogenitas, $\mathrm{pH}$ sediaan, daya sebar dan efektivitas gel sabun wajah.

\section{HASIL DAN PEMBAHASAN}

\subsection{Ekstrak Daun Kemangi}

Proses ekstraksi menggunakan metode maserasi dengan plearut etanol 96\%, karena metode ini sangat sederhana dan biasa digunakan dalam penelitian pada umumnya yaitu dengan merendam simplisia di dalam pelarut dengan suhu ruang untuk mencegah atau meminimalisir kerusakan metabolit pada simplisia. Dalam pembuatan ekstrak 160 gram serbuk daun kemangi dalam maserasi \pm 3 hari, wadah selalu dalam keadaan tertutup sambil sesekali diaduk agar kandungan senyawa terlepas lebih pekat. Hasil pembuatan ekstrak daun kemangi diperoleh ekstrak kental sebanyak 15 gram dan setelah itu di uapkan menggunakan penangas air selama \pm 1 jam hingga larutan menguap dan hanya ekstrak kental yang tersisa. [6]

\subsection{Uji Organoleptik}

Uji organoleptik ini perlu dilakukan untuk mengetahui mutu dari sediaan ekstrak gel sabun daun kemangi. Hasil uji organoleptik dapat dilihat pada tabel I.

Tabel I. Hasil Uji Organoleptik

\begin{tabular}{cccc}
\hline Jenis Gel Sabun & Bentuk & Warna & Bau \\
\hline Formula I & Kental & Hijau muda & $\begin{array}{c}\text { Aroma khas ekstrak daun } \\
\text { kemangi }\end{array}$ \\
Formula II & Kental & Hijau daun & $\begin{array}{c}\text { Aroma khas ekstrak daun } \\
\text { kemangi }\end{array}$ \\
Formula III & Kental & Hijau kehitaman & $\begin{array}{c}\text { Aroma khas ekstrak daun } \\
\text { kemangi }\end{array}$ \\
\hline
\end{tabular}

Pengujian organoleptik formula I, II dan III gel sabun memiliki bentuk kental yang merupakan karakteristik dari gel sabun pada umumnya. Warna hijau dalam sediaan merupakan ekstrak etanol daun kemangi yang berwarna hijau pekat sehingga gel sabun wajah yang dihasilkan tidak jernih dan tidak tembus cahaya. Hal ini terlihat dari perubahan warna dari gel sabun wajah yang semula berwarna putih menjadi hijau muda pada formula I, hijau daun pada formula II, dan hijau kehitaman pada formula III. Sehingga semakin tinggi kadar ekstrak maka warnanya semakain gelap. Dan juga dengan aroma khas ekstak daun kemangi yang tercium dari 
gel sabun wajah dengan formula I, II dan III diketahui semakin tinggi kadar ekstrak maka semakin tercium aroma khas daun kemangi.[7]

\subsection{Uji Homogenitas}

Uji homogenitas untuk mengetahui sediaan yang dibuat homogen atau tidak, karena dalam pembuatan sediaan gel sabun yang baik harus homogen dan bebas dari partikel yang menggumpal serta tidak ada butiran kasar. Hasil dari uji homogenitas dapat dilihat pada tabel II.

Tabel II. Hasil Uji Homogenitas

\begin{tabular}{cc}
\hline Jenis Gel Sabun & \multicolumn{1}{c}{ Homogenitas } \\
\hline Formula I & Homogen, tidak ada butiran kasar \\
Formula II & Homogen, tidak ada butiran kasar \\
Formula III & Homogen, tidak ada butiran kasar \\
\hline
\end{tabular}

Berdasarkan hasil pengamatan formula I, II dan III gel sabun yang dihasilkan sesuai dengan persyaratan homogentitas yaitu homogen dan tidak ada butiran kasar dalam formula gel sabun. Semua formula menunjukkan susunan yang homogen yang ditandai dengan tidak terdapat butiran kasar pada sediaan gel sabun.[7] Dapat disimpulkan homogenitas suatu sediaan mempengaruhi kualitas sediaan ketika digunakan.

\subsection{Uji pH Sediaan}

Uji PH pada sediaan dengan menggunakan kertas $\mathrm{pH}$. Persyaratan $\mathrm{pH}$ sediaan yang memenuhi kriteria pH kulit yaitu berkisar 4,5-6,5. Hasil uji pH dapat dilihat pada tabel III.

Tabel III. Hasil Uji pH

\begin{tabular}{lc}
\hline Jenis Gel Sabun & Nilai pH \\
\hline Formula I & 10 \\
Formula II & 9 \\
Formula III & 8 \\
\hline
\end{tabular}

Berdasarkan gambar di atas, hasil setiap formula memiliki $\mathrm{pH}$ yang tinggi sehingga tidak memenuhi kriteria $\mathrm{pH}$ kulit yaitu 4,5-6,5. Hal ini dikarenakan bahan tambahan seperti sodium lauril sulfat dan larutan $\mathrm{NaOH}$ mempengaruhi $\mathrm{pH}$ pada gel sabun. Sabun dalam bentuk gel hampir sama dengan sabun cair yang dapat dipakai untuk sabun muka atau sabun jenis lainnya.[8] Berdasarkan SNI 06-4085-1996 bahan dasar sabun dan bahan dasar deterjen memiliki pH yang berbeda yaitu bahan dasar sabun 8-11 sedangkan bahan dasar deterjen 6-8.[9] Adapun faktor lain yang mempengaruhi $\mathrm{pH}$ gel sabun wajah ekstrak daun kemangi yaitu keterbatasan alat. Pada saat proses pengujian $\mathrm{pH}$ peneliti tidak menggunakan $\mathrm{pH}$ digital, namun menggunakan kertas $\mathrm{pH}$ dimana peneliti harus teliti dengan indra pengeliatan. Sediaan gel sabun yang tidak memenuhi kriteria $\mathrm{pH}$ kulit dapat mengiritasi kulit dan menyebabkan kulit kering. Sediaan gel sabun yang memiliki $\mathrm{pH}$ yang cukup basa akan meningkatkan $\mathrm{pH}$ kulit, sedangkan pada kulit kering dapat mengembalikan $\mathrm{pH}$ kulit seperti semula dalam jangka waktu 15-30 menit.[10]

\subsection{Uji Daya Sebar}

Uji daya sebar sediaan gel sabun untuk menjamin tersebarnya gel sabun ketika diaplikasikan pada kulit. Hasil saat pengujian daya sebar dapat dilihat pada tabel IV.

Tabel IV. Hasil Pengujian Daya Sebar

\begin{tabular}{cc}
\hline Jenis Gel Sabun & Diameter Sebar Gel Sabun \\
\hline Formula I & $6,5 \mathrm{~cm}$ \\
Formula II & $6,5 \mathrm{~cm}$ \\
\hline
\end{tabular}




Formula III $6,5 \mathrm{~cm}$

Uji daya sebar merupakan salah satu syarat sediaan gel sabun wajah yang baik. Hasil dari uji daya sebar yaitu 5-7 cm sehingga menunjukan konsitensi semi solid yang sangat nyaman dalam penggunaan. Suatu sediaan yang memiliki daya sebar tinggi maka semakin besar daerah penyebarannya sehingga zat aktif yang terkandung akan tersebar merata menyebabkan efek terapi menjadi lebih efektif. Hasil daya sebar gel sabun wajah formula I, II dan III memiliki daya sebar $6,5 \mathrm{~cm}$. Sehingga dari hasil bahwa daya sebar gel sabun wajah masuk rentang 5-7 $\mathrm{cm}$, hal ini dapat disebabkan karena gel sabun wajah memiliki bentuk yang kental.[11]

\subsection{Uji Efektivitas Gel Sabun Wajah}

Uji efektivitas antibakteri dilihat dari besarnya pelepasan zat aktif dengan mengukur zona hambat/zona jernih pada sumuran yang diukur setelah masa inkubasi 24 jam menggunakan mistar berskala. Diameter zona hambat bakteri Staphylococcus aureus digunakan variasi tiga formula serta tanpa ekstrak daun kemangi. Variasi formula bertujuan untuk membandingkan ekfetivitas dari setiap formula yang besifat antibakteri terhadap Staphylococcus aureus. Kriteria kekuatan daya antibakteri sebagai berikut :[9]

a. Diameter zona hambat kurang dari $5 \mathrm{~mm}$ dikatagorikan lemah

b. Diameter zona hambat $5-10 \mathrm{~mm}$ dikatagorikan sedang

c. Diameter zona hambat $10-20 \mathrm{~mm}$ dikatagorikan kuat

d. Diameter zona hambat $20 \mathrm{~mm}$ atau lebih dikatagorikan sangat kuat.

Uji efektivitas dilakukan dengan metode difusi agar yang bertujuan untuk mengetahui diameter zona hambat. Uji efektivitas dilihat dari besarnya pelepasan zat aktif yang dapat diketahui dengan mengukur zona hambat (zona jernih) pada sumuran dengan menggunakan mistar berskala setelah masa inkubasi 24 jam. Pengukuran diameter zona hambat bakteri Staphylococcus aureus dilakukan pada ketiga formula serta tanpa ekstrak daun kemangi. Tujuan uji formula yang divariasi untuk dibandingkan efektivitas pada tiap formula yang besifat antibakteri terhadap Staphylococcus aureus.[10] Hasil pengujian efektivitas gel sabun wajah dapat dilihat pada tabel V.

Tabel V. Hasil Diameter Zona Hambat

\begin{tabular}{cc}
\hline Jenis Gel Sabun & Diameter Zona Hambat \\
\hline Formula I & $5 \mathrm{~mm}$ \\
Formula II & $8 \mathrm{~mm}$ \\
Formula III & $9 \mathrm{~mm}$ \\
Formula Tanpa ekstrak & $(-)$ \\
\hline
\end{tabular}

Hasil ekstrak daun kemangi dapat diketahui berdasarkan kriteria ketiga formula menujukan efek sedang yang sama dalam menghambat pertumbuhan bakteri Staphylococcus aureus. Daya hambat ketiga formula gel sabun wajah ekstrak daun kemangi terhadap bakteri Staphylococcus aureus termasuk katagori zona hambat sedang, tetapi yang memiliki daya hambat yang paling luas yaitu FIII : 9 mm mendekati zona hambat kuat. Hal ini dikarenakan ekstrak daun kemangi memiliki daya hambat yang berpontensi sebagai antibakteri sudah cukup terkandung di dalamnya sehingga dapat menghambat pertumbuhan bakteri. Menurut penelitian sebelumnya kandungan senyawa yang dapat menghambat pertumbuhan bakteri Staphylococcus 
aureus dalam gel ekstrak daun kemangi terdiri dari flavonoid, minyak atsiri dan tanin termasuk senyawa fenol yang dapat memberikan efek antibakteri.[4] Senyawa flavonoid memiliki efek farmakologi menghambat sintesis asam nukleat, menghambat fungsi membran sitoplasma dan menghambat metabolisme energi sel. Sedangkan senyawa fenol berperan merusak membran mikroba dan menstimulasi terganggunya ion-ion kalium sel sehingga rusak membran sel.[12]

Berdasarkan penelitian ini, faktor lain yang mempengaruhi zona hambat gel sabun wajah ekstrak daun kemangi terhadap bakteri Staphylococcus aureus yaitu pada saat proses inkubasi yang menggunakan inkubator manual. Inkubator yang seharusnya digunakan dalam penelitian yaitu menggunakan inkubator sesuai standar. Namun karena keterbatasan alat penelitian, peneliti menggunakan inkubator manual yang digunakan untuk inkubasi selama 24 jam dengan suhu yang tidak teratur. Selain itu, perbedaan variasi ekstrak pada formula dapat mempengaruhi efekvitas bakteri Staphylococcus aureus terhadap zona hambat gel sabun wajah. Ini membuktikan bahwa semakin tinggi ekstrak daun kemangi, maka luas zona hambat semakin lebar yang terbentuk di sekitar sumuran.[6]

\section{KESIMPULAN}

Sediaan gel sabun wajah ekstrak daun kemangi (Ocimum basilicum L.) memiliki efektivitas dengan zona hambat sedang terhadap bakteri Staphylococcus aureus, tetapi yang memiliki daya hambat yang paling luas yaitupada Formula III : $9 \mathrm{~mm}$ mendekati zona hambat kuat.

\section{DAFTAR PUSTAKA}

[1] Hafsah, Izzati saila., dan Andono, Pulung Nurtantion, Deteksi Otomatis Penyakit Kulit Menggunakan Algoritma Naive Bayes, JNN Semarang, No. 5, 2015, hal 1-6.

[2] Sukmawati, Ellyzabeth., Efektivitas Penggunaan Daun Sirih Merah Untuk Mengurangi Jerawat Pada Remaja, Global Health Science, Vol. 1 issue 1, March 2016, hal 36-42.

[3] Kurnianingsih, Dewi., Setiabudi, Lulu., Tajudin, Tatang, Uji Efektivitas Sediaan Krim Kombinasi Ekstrak Daun Bakau Hitam (Rhizophora Mucronata) Dan Jeruk Purut (Citrus Hystrix) Terhadap Bakteri Staphylococcus Aureus, Jurnal Ilmiah Jophus : Journal of Pharmacy UMUS, Vol. 2 No. 01, Agustus 2020.

[4] Angelina, M., Turnip, M., dan Khotimah. S., Uji Aktivitas Antibakteri Ekstrak Daun Kemangi (Ocimum Sanctum L.) terhadap Bakteri Esherichia coli dan Staphylococcus aureus, Jurnal Protobiont, Vol. 4 No. 1, 2015, hal 184-189.

[5] Khalil, A., Antimicrobial Activity of Ethanolic Extracts of Ocimum basilicum leaf from Saudi Arabia, Biotechnology, Vol. 12 No. 1, 2013, hal 61-64.

[6] Budiati, Anarisa., Purba, Anny Victor., dan Kumala, Shirly., Pengembangan Produk Gel Sabun Wajah Ekstrak Buah Belimbing Wuluh (Averrha bilimbi L.) dan Daun Sosor Bebek (Kalanchoe piinata (Lam.) Per.) sebagai Antibakteri Penyebab Jerawat, Jurnal Ilmu Kefarmasian Indonesia, Vol. 15 No. 1, April 2017, hal 89-95.

[7] Kindangen, Ofirnia Clara., Yamlean, Paulina V. Y., Wewengkang, Defny S., Formulasi Gel Antijerawat Ekstrak Etanol Daun Kemangi (Ocimum basilicum L.) Dan Uji Aktivitasnya terhadap Bakteri Staphlococcus aureus Secara in vitri, Pharmacon Jurnal Ilmiah Farmasi, Vol. 7 No. 3, Agustus 2018, hal 283-293.

[8] Muliyawan, Dewi dan Suriana, Neti, A-z tentang Koametik, Jakarta, PT Elex Media Komputido Kelompok Gramedia, 2013, hal. 257.

[9] SNI. 1996. Batas Maksimum Sabun Cair, Bogor, Badan Standarisasi Nasional.

[10] Rastina., Sudarwanto, Mirnawati dan Wientarsih, Ietje., Aktivitas Antibakteri Ekstrak Etanol Daun Kari (Murraya Koenigii) Terhadap Staphylococcus aureus, Escherichia coli dan Pseudomonas sp, Jurnal Kedokteran Hewan, Vol. 9 No. 2, September 2015, hal 1-4. 
[11] Priawanto, Panji Gelora dan Hadning, Ingenida, Formulasi Dan Uji Kualitas Fisik Sediaan Gel Getah Jarak (Jatropha curcas), Naskah Publikasi Karya Tulis Ilmiah, Agustus 19, 2017, hal. 1-14.

[12] Threenesia, Atika., Skripsi, Perbandingan Efek pemberian Ekstrak Etanol Daun Kemangi (Ocimum sanctum L.) Terhadap Daya Hambat Pertumbuhan Staphylococcus aureus dan salmonella typhi Secara in vitro, Fakultas Kedokteran, Univ. Lampung, 2017, hal 14-15. 